\title{
Systemic Injection of FGF-2 Stimulates Endocortical Bone Modelling in SAMP6, a Murine Model of Low Turnover Osteopenia
}

\author{
Hirofumi NAGAI, Ryoichi TSUKUDA, Hideki YAMASAKI and Hiroshi MAYAHARA \\ Drug Safety Research Laboratories, Takeda Chemical Industries, Ltd., 17-85, Juso-honmachi 2-chome, Yodogawa-ku, Osaka 532-8686, \\ Japan
}

(Received 4 February 1999/Accepted 26 March 1999)

\begin{abstract}
The effects of systemically administered fibroblast growth factor-2 (FGF-2) at doses of 0.1 and $0.3 \mathrm{mg} / \mathrm{kg} / \mathrm{day}$ for $7 \mathrm{days}$ were investigated 5-week-old male SAMP6 mice, a model of low turnover osteopenia. The bone histomorphometry in the distal epiphyseal growth plate of the femur showed that $0.3 \mathrm{mg} / \mathrm{kg} / \mathrm{day}$ of FGF-2 decreased the longitudinal growth rate and cartilage cell production rate and increased the growth plate width. Growth plate chondrocytes showed the features of defective endochondral ossification at the same dosage level. In the distal one third of the femur, the marrow trabecular area, endocortical mineral apposition rate and/or bone formation rate were increased in both the SAMP6 mice given 0.1 and $0.3 \mathrm{mg}$ of FGF- $2 / \mathrm{kg} / \mathrm{day}$. In this region, the endocortical osteoblasts were hypertrophied with some layers of overlying proliferated fibroblastic mesenchymal cells. The presence of small foci of bone formation within the layers of these mesenchymal cells indicates their osteogenic potential. On the other hand, the periosteal bone formation rate in the mid-shaft of the femur was depressed in the $0.3 \mathrm{mg} / \mathrm{kg} / \mathrm{day}$ group. These results suggest that systemically administered FGF-2 may have the possibility to increase the peak bone mass in SAMP6 by stimulating the osteoprogenitor cells to proliferate and differentiate into osteoblasts and enhancing endocortical bone modelling. The higher dose of FGF-2, however, inhibited both endochondral and periosteal bone formation.-KEY EORDS: bone histomorphometry, bone modelling, osteoporosis, SAM.
\end{abstract}

J. Vet. Med. Sci. 61(8): 869-875, 1999

The senescence-accelerated mouse prone 6 (SAMP6) was developed as an animal model of senile osteoporosis characterized by low peak bone mass $[13,25]$. The pathogenesis of age-related osteopenia is not yet fully understood; however, a decrease in endosteal bone formation during cortical bone modelling has been considered a crucial element in the development of the low peak bone density seen in SAMP6 [26]. Takahashi et al. reported that the bone mass in SAMP6 was increased when the lysate of cells derived from the bone marrow of SAMP2, a control strain for SAMP6 with higher peak bone mass, was injected [24]. These findings suggested that some factor(s) in bone marrow-derived cells might be a determinant of the rate of endosteal bone formation and peak bone mass in SAMP6.

A number of growth factors have been isolated from bone tissue and have been considered to act as local regulators of bone formation [4]. Fibroblast growth factor-2 (FGF-2) is one of the most abundant growth factors in bone where it is synthesized by osteoblasts and is stored in an active form in the extracellular matrix [3, 6]. Most information on FGF-2 effects on bone has been obtained from in vitro studies, and it has been shown that FGF-2 stimulates bone cell replication but inhibits the expression of the osteoblastic phenotypes $[1,7,20]$. Recent in vivo studies have demonstrated that exogenous FGF-2 and the related peptides FGF-1 and FGF4 stimulate osteogenic cell proliferation and subsequent mineralized bone formation on the endosteal bone surface in rats [14-17].

The purpose of this study was to determine whether daily systemic injection of FGF-2 would stimulate bone formation and increase bone mass in the spontaneously osteopenic mouse, SAMP6, in the course of bone modelling.

\section{MATERIALS AND METHODS}

Animals: Five-week-old male SAMP6/Ta mice were used. SAMP6/Ta, a substrain of SAMP6, were reared under specific pathogen-free conditions in the Experimental Animal Unit, Takeda Chemical Industries, Ltd. The osteopenic state in SAMP6/Ta was documented in our previous report [27]. We selected 5-week-old mice for the present experiment according to the following reasons: The low femoral bone mass was first recognized in SAMP6 mice at about 4 weeks of age and increased until about 9 weeks of age, and during this period, decreased endosteal bone formation in SAMP6 mice was observed [26]. Two days before beginning FGF-2 administration, the mice were weighed and divided into three groups of 6 mice each. During the experiment, the mice had free access to tap water and a pelleted commercial diet (CE-2, Clea Japan, Inc., Tokyo).

Experimental protocol: Recombinant human FGF-2 mutein CS23 in which Cys 70 and Cys 88 have both been replaced with Ser residues was used as the FGF-2 peptide, $18-\mathrm{kDa}$ moiety, in the present study [22]. Each group of mice received vehicle $(50 \mathrm{mM}$ citrate buffer, $\mathrm{pH} 7.0)$ or FGF-2 at a dose of 0.1 or $0.3 \mathrm{mg} / \mathrm{kg}$ body weight intravenously, via the tail vein, daily for 7 days, from Day 0 to Day 6.

All mice received a subcutaneous injection of $90 \mathrm{mg}$ of xylenol orange/kg (Wako Pure Chemical, Inc., Tokyo) 1 day before beginning FGF-2 administration (Day -1) and 10 $\mathrm{mg}$ of calcein $/ \mathrm{kg}$ (Sigma Chemical Co., St. Louis, MO) on Day 6.

One day after the last dose (Day 7), all mice were 
anesthetized with ether and sacrificed by exsanguination via the abdominal aorta.

Histology: The left femur was dissected, fixed in $10 \%$ buffered formalin, decalcified in 5\% formic acid and embedded in paraffin. A parasaggital section of the distal half of the femur was stained with hematoxylin and eosin and examined under a light microscope.

Processing of Bones: The right femur was removed, defleshed and fixed in $70 \%$ alcohol for histomorphometric examination. Bones were immersed in 5\% Villanueva bone stain in $70 \%$ methanol for 3 days, dehydrated through sequential changes of alcohol and acetone and embedded in methyl methacrylate. The transverse sections at the midshaft of the femur and the one third proximal to the femoral distal end and a parasaggital section of the distal femur were sawed at $250 \mu \mathrm{m}$, ground to a thickness of $20 \mu \mathrm{m}$ and covered with coverslips $[8,16]$.

Bone Histomorphometry: Histomorphometric analyses were performed using an episcopic fluorescent microscope link to a semi-automatic image analyzer system (IBAS-2000, Carl Zeiss, Germany).

The parasaggital section of the distal femur was used to measure the distance between calcein label and the growth cartilage metaphyseal junction (a substitute for the distance between labels), growth plate width and the hight of the degenerative cells. The measurements were used to calculate the longitudinal growth rate (distance between labels/labeling time, i.e., 1 day) and the cartilage cell production rate (longitudinal growth rate/degenerative cell size) [8].

In the cross sections of the femur, we measured the total tissue area (the area surrounded by the periosteum), marrow area and marrow trabecular area. These parameters were used to calculate the percentages of cortical, marrow and marrow trabecular areas. The dynamic histomorphometric parameters, periosteal and endocortical labeled perimeters, and the area between the xylenol orange (Day -1) and the calcein (Day 6) markers were measured. The mean distance between labels was calculated by dividing the interlabeling area by half of the length of the xylenol orange label plus the calcein label [16]. The mineral apposition rate was estimated by dividing the mean interlabeling distance by the interlabeling interval (7 days) [19]. The bone formation rate was calculated by dividing the interlabeling area by the interlabeling interval [19].

Statistical Analysis: Data on bone histomorphometry are expressed as the mean \pm SEM. Data were evaluated by the protected least significant difference method to compare each of the group means with the control mean. All statistical tests were conducted at the 5\% two-tailed probability levels.

\section{RESULTS}

Histologic Examination: In the mice given $0.3 \mathrm{mg}$ of FGF-2/kg/day, the epiphyseal growth plate was thickened and mainly composed of hypertrophic chondrocytes with irregular arrangement. Some of the chondrocytes in the degenerative stage were atrophied, and the continuity between the cartilage column and the primary spongiosa was partly lost (Fig. 1c). No abnormal changes in the growth plate were observed in $0.1 \mathrm{mg} / \mathrm{kg} /$ day group (Fig. 1b).

In the distal diaphysis of the femur, the osteoblasts lining the endocortical surface were hypertrophied, and several layers of proliferated fibroblastic mesenchymal cells were observed over the osteoblast layer (Fig. 2b and c). Occasionally, small foci of bone formation were noted within the layers of proliferated mesenchymal cells (Fig. 2b and $\mathrm{c}$ ).

Histomorphometry in the Growth Plate: The histomorphometric parameters determined in the distal epiphyseal growth plate are given in Table 1. The longitudinal growth rate, mean size of degenerative cells and cartilage cell production rate were significantly decreased and the growth plate width was increased in SAMP6 receiving $0.3 \mathrm{mg}$ of FGF-2/kg/day. Fluorescent microscopy revealed that the calcein label beneath the growth cartilage metaphyseal junction showed an irregular appearance and was partially lacking in the mice given 0.3 $\mathrm{mg}$ of FGF-2/kg/day (Fig. 3c). No significant changes were observed in the mice treated with $0.1 \mathrm{mg}$ of FGF-2/kg/ day.

Histomorphometry in the Distal One Third of the Femur: Table 2 shows the effects on static histomorphometric parameters of the distal one third of the femur. The entirely labeled new marrow trabecular bone were observed close to the endocortical surface and the marrow trabecular area was increased in a dose-dependent manner with statistical significance being noted in the animals treated with $0.3 \mathrm{mg}$ of FGF-2/kg/day (Fig. 4b and c).

The dynamic histomorphometric parameters of the distal one third of the femur are shown in Table 3. All of the endocortical surface was labeled in all animals, and the bone formation rate in the mice given 0.1 and $0.3 \mathrm{mg}$ of FGF-2/ $\mathrm{kg} / \mathrm{day}$ and the mineral apposition rate in the $0.1 \mathrm{mg} / \mathrm{kg} / \mathrm{day}$ group were significantly increased on the endocortical surface of the distal one third of the femur compared with the control value. Almost no labels were observed on the periosteal surface.

Histomorphometry in the Mid-Shaft of the Femur: No statistically significant changes were noted in the static histomorphometric parameters of the mid-shaft of the femur in the animals treated with FGF-2 (Table 4).

The dynamic histomorphometric parameters of the midshaft of the femur are shown in Table 5. The fluorochrome labels surrounded the entire periosteal surface of all animals in the treated and control groups except in the case of one of the six mice in the $0.3 \mathrm{mg} / \mathrm{kg} / \mathrm{day}$ group: Only $79.5 \%$ of the surface was labeled in this animal. The periosteal bone formation rate in the $0.3 \mathrm{mg} / \mathrm{kg} / \mathrm{day}$ group was significantly decreased. The endocortical dynamic parameters were not significantly affected by FGF-2 administration. It possibly be due to the drifting of the mid-shaft during growth, the 


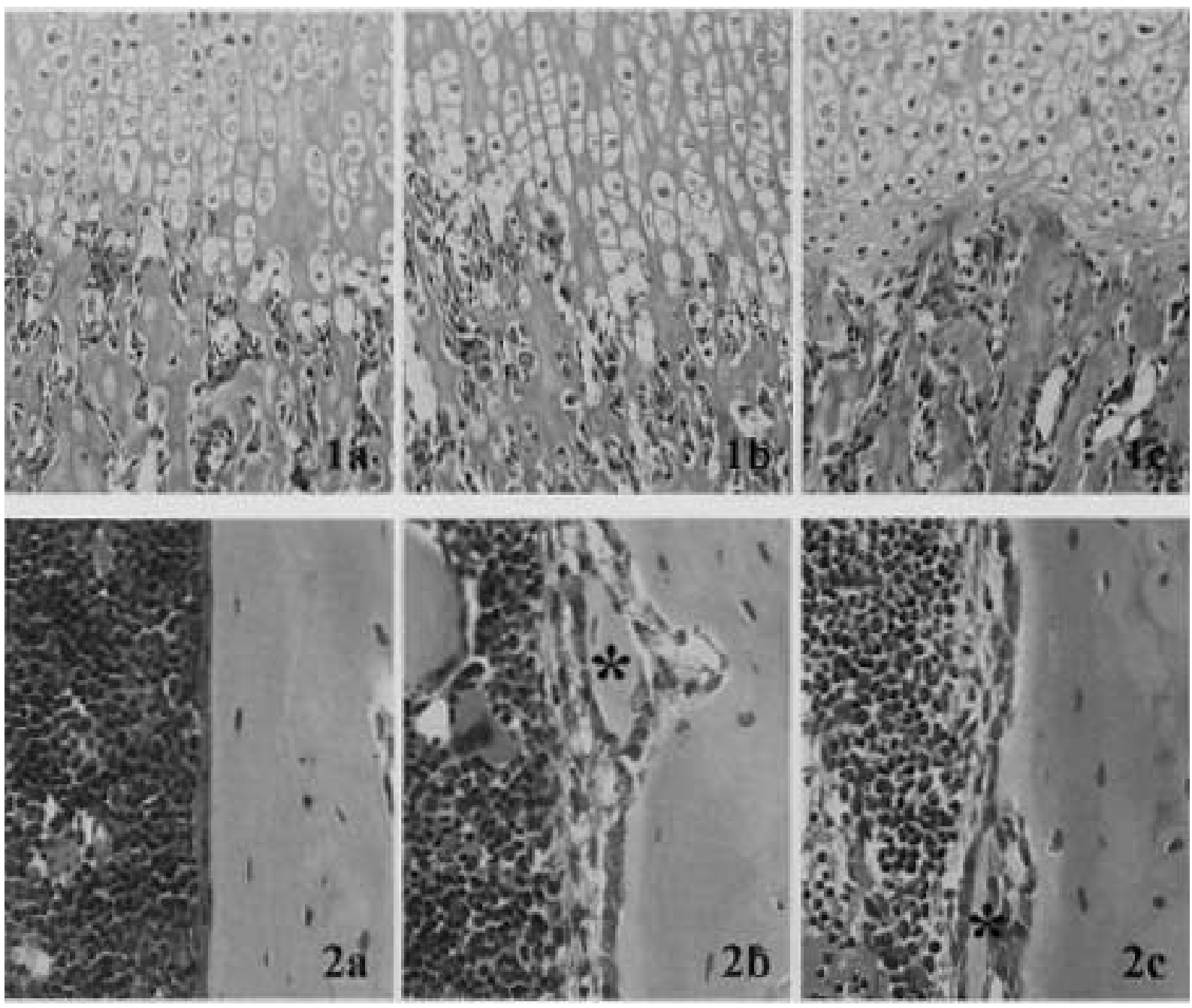

Fig. 1. Light micrographs of the growth plate cartilage metaphyseal junction in SAMP6 mouse given daily injections of FGF-2 for 7 days. a) Control. b) The $0.1 \mathrm{mg} / \mathrm{kg}$ group. c) The $0.3 \mathrm{mg} / \mathrm{kg}$ group. No abnormalities are noted in the $0.1 \mathrm{mg} / \mathrm{kg}$ group. In the 0.3 $\mathrm{mg} / \mathrm{kg}$ group, the chondrocytic column shows irregular arrangement, and the degenerative chondrocytes are atrophied and the continuity between the cartilage column and the primary spongiosa is lost. Hematoxylin and eosin stain, $\times 155$.

Fig. 2. Light micrographs of the endocortical bone surface of the distal diaphysis in SAMP6 mouse given daily injections of FGF-2 for 7 days. a) Control. b) The $0.1 \mathrm{mg} / \mathrm{kg}$ group. c) The $0.3 \mathrm{mg} / \mathrm{kg}$ group. In both the 0.1 and $0.3 \mathrm{mg} / \mathrm{kg}$ groups, the osteoblasts lining the endocortical surface are hypertrophied, and several layers of fibroblastic mesenchymal cells are observed over the osteoblast layer. Note the bone formation within the mesenchymal cell layers (asterisk). Hematoxylin and eosin stain, $\times 340$.

Table 1. Bone histomorphometry in distal epiphyseal growth plate of the femur

\begin{tabular}{ccccc}
\hline Dose & $\begin{array}{c}\text { Growth plate } \\
\text { width }(\mu \mathrm{m})\end{array}$ & $\begin{array}{c}\text { Longitudinal growth } \\
\text { rate }(\mu \mathrm{m} / \text { day })\end{array}$ & $\begin{array}{c}\text { Hight of degene- } \\
\text { rative cells }(\mu \mathrm{m})\end{array}$ & $\begin{array}{c}\text { Cell production } \\
\text { rate (cells/day) }\end{array}$ \\
\hline Control & $236 \pm 24$ & $64.0 \pm 3.1$ & $20.0 \pm 0.6$ & $3.21 \pm 0.17$ \\
$0.1 \mathrm{mg} / \mathrm{kg}$ & $245 \pm 25$ & $62.1 \pm 2.0$ & $19.8 \pm 0.9$ & $3.17 \pm 0.12$ \\
$0.3 \mathrm{mg} / \mathrm{kg}$ & $428 \pm 33^{* *}$ & $14.8 \pm 3.4^{* *}$ & $13.5 \pm 0.6^{* *}$ & $1.09 \pm 0.23^{* *}$ \\
\hline
\end{tabular}

Mean \pm SEM, $N=6, * * \mathrm{p}<0.01$.

length of labeled endocortical surface was limited and varied between individuals (data not shown).

\section{DISCUSSION}

Decreased endosteal bone formation during cortical bone modelling is thought to play a crucial role in the 

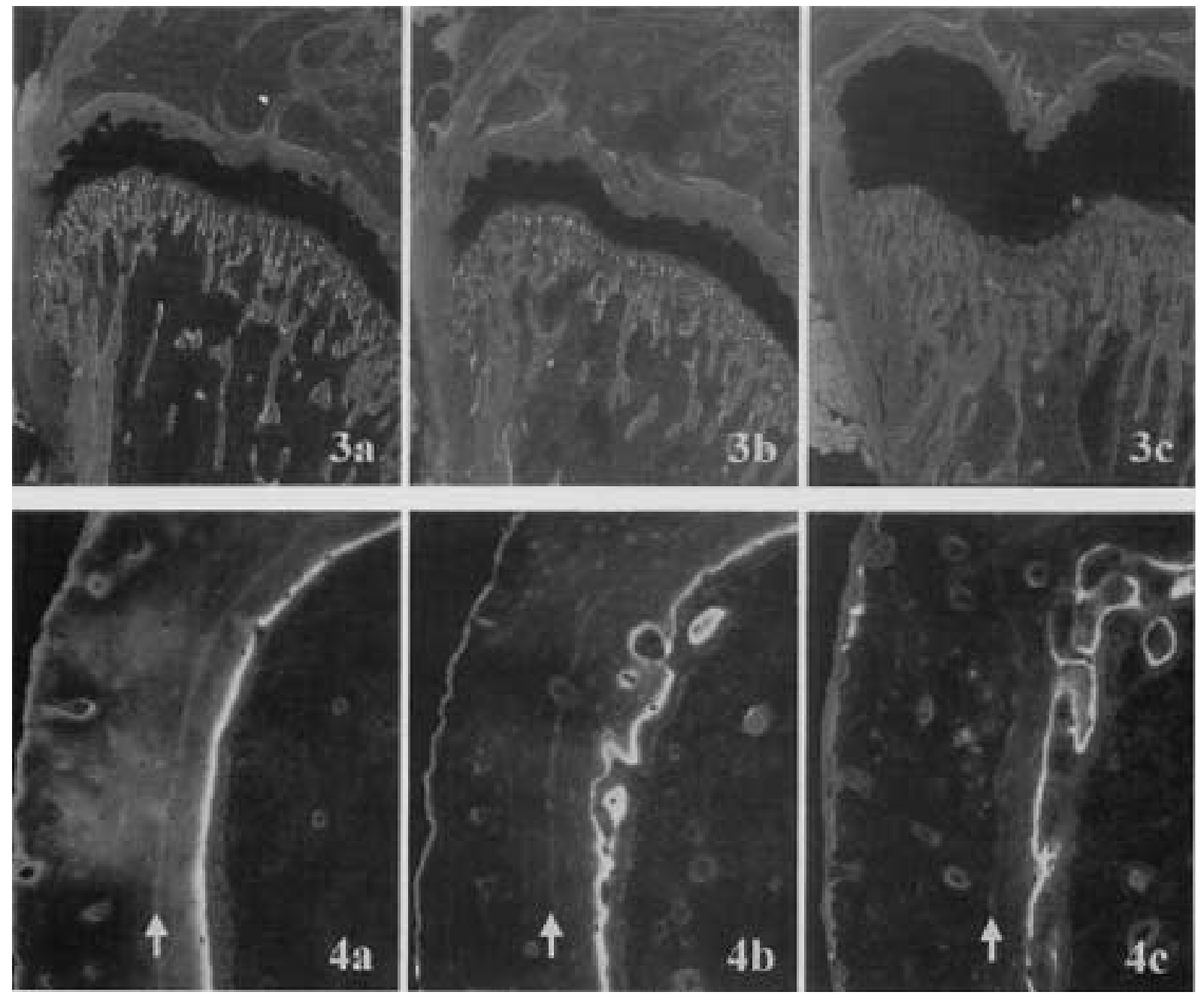

Fig. 3. Fluorescent micrographs of the distal femur in SAMP6 mouse given daily injections of FGF-2 for 7 days. a) Control. b) The $0.1 \mathrm{mg} / \mathrm{kg}$ group. c) The $0.3 \mathrm{mg} / \mathrm{kg}$ group. No distinct changes are noted in the $0.1 \mathrm{mg} / \mathrm{kg}$ group. In the $0.3 \mathrm{mg} / \mathrm{kg}$ group, the growth plate was thickened, and the calcein labels beneath the growth plate cartilage metaphyseal junction are indistinct and partially lacking. Villanueva bone stained, $20 \mu \mathrm{m}$ thick, undecalcified ground sections, $\times 28$.

Fig. 4. Fluorescent micrographs of the cross section of the distal one third of the femur in SAMP6 mouse given daily injections of FGF-2 for 7 days. a) Control. b) The $0.1 \mathrm{mg} / \mathrm{kg}$ group. c) The $0.3 \mathrm{mg} / \mathrm{kg}$ group. Marrow trabeculae are noted in both the 0.1 and 0.3 $\mathrm{mg} / \mathrm{kg}$ groups. The interlabeling width between the xylenol orange (arrow) and endosteal calcein labels in the $0.1 \mathrm{mg} / \mathrm{kg}$ group is wider than that in the control group. Villanueva bone stained, $20 \mu \mathrm{m}$ thick, undecalcified ground sections, $\times 130$

Table 2. Static bone histomorphometry in the distal one third of the femur

\begin{tabular}{ccccc}
\hline Dose & $\begin{array}{c}\text { Tissue area } \\
\left(\mathrm{mm}^{2}\right)\end{array}$ & $\begin{array}{c}\text { Marrow area } \\
(\%)\end{array}$ & $\begin{array}{c}\text { Cortical bone } \\
\text { area }(\%)\end{array}$ & $\begin{array}{c}\text { Marrow trabecular } \\
\text { area }(\%)\end{array}$ \\
\hline Control & $2.04 \pm 0.05$ & $56.3 \pm 0.6$ & $43.7 \pm 0.6$ & $0.46 \pm 0.21$ \\
$0.1 \mathrm{mg} / \mathrm{kg}$ & $2.10 \pm 0.05$ & $57.7 \pm 0.8$ & $42.3 \pm 0.8$ & $1.38 \pm 0.49$ \\
$0.3 \mathrm{mg} / \mathrm{kg}$ & $2.10 \pm 0.06$ & $56.2 \pm 0.9$ & $43.8 \pm 0.9$ & $2.09 \pm 0.46^{*}$ \\
\hline
\end{tabular}

Mean \pm SEM, $N=6,{ }^{*} p<0.05$.

development of the low peak bone mass in SAMP6 mice, a model of low turnover osteopenia [26]. Previous ex vivo experiments strongly suggested that the osteopenic state in SAMP6 is due to a premature decrease in osteoblast progenitor cells in the bone marrow [9, 23]. It is believed that bone marrow stromal cells contain a multipotent selfrenewing compartment and are capable of differentiating into several mesenchymal lineages: Osteoblasts, 
Table 3. Dynamic bone histomorphometry in the distal one third of the femur

\begin{tabular}{ccc}
\hline Dose & $\begin{array}{c}\text { Endocortical mineral } \\
\text { apposition rate } \\
(\mu \mathrm{m} / \text { day })\end{array}$ & $\begin{array}{c}\text { Endocortical bone } \\
\text { formation rate } \\
\left(\mu \mathrm{m}^{2} / \text { day } \times 10^{-4}\right)\end{array}$ \\
\hline Control & $3.32 \pm 0.29$ & $1.31 \pm 0.16$ \\
$0.1 \mathrm{mg} / \mathrm{kg}$ & $4.26 \pm 0.31^{*}$ & $1.79 \pm 0.15^{*}$ \\
$0.3 \mathrm{mg} / \mathrm{kg}$ & $4.16 \pm 0.23$ & $1.78 \pm 0.14^{*}$ \\
\hline
\end{tabular}

Mean \pm SEM, $N=6, * p<0.05$.
Table 4. Static bone histomorphometry in the femoral mid-shaft

\begin{tabular}{cccc}
\hline Dose & $\begin{array}{c}\text { Tissue area } \\
\left(\mathrm{mm}^{2}\right)\end{array}$ & $\begin{array}{c}\text { Marrow area } \\
(\%)\end{array}$ & $\begin{array}{c}\text { Cortical bone } \\
\text { area }(\%)\end{array}$ \\
\hline Control & $1.49 \pm 0.01$ & $46.6 \pm 1.0$ & $53.4 \pm 1.0$ \\
$0.1 \mathrm{mg} / \mathrm{kg}$ & $1.49 \pm 0.02$ & $46.5 \pm 1.1$ & $53.5 \pm 1.1$ \\
$0.3 \mathrm{mg} / \mathrm{kg}$ & $1.52 \pm 0.01$ & $47.1 \pm 0.5$ & $52.9 \pm 0.5$ \\
\hline
\end{tabular}

Mean $\pm \mathrm{SEM}, \mathrm{N}=6$, No statistical significance.

Table 5. Dynamic bone histomorphometry in the femoral mid-shaft

\begin{tabular}{ccccc}
\hline Dose & $\begin{array}{c}\text { Periosteal mineral } \\
\text { apposition rate } \\
(\mu \mathrm{m} / \text { day })\end{array}$ & $\begin{array}{c}\text { Periosteal bone } \\
\text { formation rate } \\
\left(\mu \mathrm{m}^{2} / \text { day } \times 10^{-4}\right)\end{array}$ & $\begin{array}{c}\text { Endocortical mineral } \\
\text { apposition rate } \\
(\mu \mathrm{m} / \text { day })\end{array}$ & $\begin{array}{c}\text { Endocortical bone } \\
\text { formation rate } \\
\left(\mu \mathrm{m}^{2} / \mathrm{day} \times 10^{-4}\right)\end{array}$ \\
\hline Control & $5.40 \pm 0.32$ & $2.37 \pm 0.12$ & $1.32 \pm 0.04$ & $1.71 \pm 0.22$ \\
$0.1 \mathrm{mg} / \mathrm{kg}$ & $5.14 \pm 0.22$ & $2.21 \pm 0.08$ & $1.26 \pm 0.15$ & $1.58 \pm 0.22$ \\
$0.3 \mathrm{mg} / \mathrm{kg}$ & $4.78 \pm 0.17$ & $2.01 \pm 0.07^{*}$ & $1.25 \pm 0.18$ & $1.29 \pm 0.22$ \\
\hline
\end{tabular}

Mean \pm SEM, $N=6,{ }^{*} \mathrm{p}<0.05$.

chondrocytes, adipocytes and myocytes [28]. In the bone marrow of SAMP6, it was reported that multipotential stem cells exhibit increased adipogenesis and myelopoiesis in contrast to decreased osteoblastogenesis [10]. Although the precise mechanisms for determining the commitment to each lineage are poorly understood, it was recently reported that FGF-2 stimulates bone marrow stromal cell proliferation and maintains their osteogenic potential $[5,12]$.

In the present study, we examined the effects of 0.1 and $0.3 \mathrm{mg}$ of FGF-2/kg/day administered intravenously for 7 days in the course of bone modelling and assessed the possibility of preventing development of the osteopenic state in SAMP6.

In the distal one third of the femur, the level where the metaphyseal funnel is formed and active endocortical bone formation occurs in growing animals [26], the endocortical osteoblasts were hypertrophied and accompanied by several layers of overlying proliferated fibroblastic mesenchymal cells in FGF-2-treated animals. Small foci of bone formation within the clusters of proliferated mesenchymal cells indicate their osteogenic potential. New marrow trabeculae were also noted in this region. These findings suggest that FGF-2 increases the osteogenic progenitor cells which can be differentiated into osteoblasts and may support sufficient endocortical bone modelling in SAMP6 mice.

Dynamic histomorphometry revealed that the endocortical mineral apposition and bone formation rates were increased in the distal one third of the femur in both dosed groups while the periosteal bone formation rate was depressed in the femoral mid-shaft in SAMP6 mice received $0.3 \mathrm{mg}$ of FGF- $2 / \mathrm{kg} /$ day. The inhibitory effect of a higher dose of FGF-2 on the ossification of the periosteal osteoblasts in SAMP6 is consistent with the observations from in vitro experiments; it has been suggested that FGF-2 has direct inhibitory effects on matrix formation and mineralization in cultured osteoblastic cells, possibly a representative of the periosteal osteoblasts $[1,7,20]$. On the other hand, increased endosteal bone formation may also be due to the direct effects of FGF-2, which recruits osteoblasts from the bone marrow stromal cell population as mentioned above and/or delays apoptosis of the osteoblasts mediated by upregulation of $\mathrm{Bcl}-2$, a protein which acts as a cellular survival factor. This inhibitory effect of FGF-2 on programmed cell death was recently demonstrated in fibroblastic cell line, NIH 3T3 cells maintained under serum free conditions [29]. Another possibility dealing with FGF2-enhanced endosteal bone formation is the activation of pre-existing osteoblasts mediated by cytokines produced by proliferating osteoprogenitor cells. Indeed, as reported earlier, FGF-2 stimulates cultured osteoblastic cells to produce type $\beta$ transforming growth factor (TGF- $\beta$ ) [18], which stimulates expression of markers of osteoblast differentiation, such as alkaline phosphatase, type I collagen and osteonectin, in most in vitro studies [11] and increases endosteal bone formation in vivo [21].

The bone histomorphometric analyses and histologic examination of the distal epiphyseal growth plate of the femur in mice given higher dose of FGF-2 revealed decreases in the longitudinal growth rate and cartilage cell production rate and a increase in the growth plate width accompanied by features of defective endochondral ossification. These findings are in agreement with those of Deng et al., who first demonstrated using a gene targeting technique that fibroblast growth factor receptor 3 (FGFR-3) is a negative regulator of endochondral bone growth [2].

In conclusion, daily intravenous injection of FGF-2 at doses of 0.1 and $0.3 \mathrm{mg} / \mathrm{kg} /$ day may have the possibility to increase the peak bone mass and prevent the osteopenic state in SAMP6 mice by stimulation of the bone marrow osteoprogenitor cells to proliferate and differentiate into 
osteoblasts and form new marrow trabecular bone. Systemically administered FGF-2 also enhances the endocortical bone formation and mineral apposition rates. The higher dose of FGF-2, however, can inhibit endochondral and periosteal bone formation.

ACKNOWLEDGEMENT. The authors thank Mr. J. A. Hogan for proofreading the manuscript.

\section{REFERENCES}

1. Canalis, E., Centrella, M. and McCarthy, T. 1988. Effects of basic fibroblast growth factor on bone formation in vitro. $J$. Clin. Invest. 81: 1572-1577.

2. Deng. C., Wynshaw-Boris, A., Zhou, F., Kuo, A. and Leder, P. 1996. Fibroblast growth factor receptor 3 is a negative regulator of bone growth. Cell 84: 911-921.

3. Globus, R. K., Plouet, J. and Gospodarowicz, D. 1989. Cultured bovine bone cells synthesize basic fibroblast growth factor and store it in their extracellular matrix. Endocrinology 124: 1539-1547.

4. Gowen, M. 1994. Cytokines and cellular interactions in the control of bone remodelling. pp. 77-114. In: Bone and Mineral Research/8 (Heersche, J. N. M. and Kanis, J. A. eds.), Elsevier, Tokyo.

5. Hanada, K., Dennis, J. E. and Caplan, A. I. 1997. Stimulatory effects of basic fibroblast growth factor and bone morphogenic protein- 2 on osteogenic differentiation of rat bone marrow-derived mesenchymal stem cells. J. Bone Miner. Res. 12: $1606-1614$.

6. Hauschka, P. V., Maurakos, A. E., Iafrati, M. D., Doleman, S. E. and Klagsbrun, M. 1986. Growth factors in bone matrix - Isolation of multiple types by affinity chromatography on heparin-sepharose. J. Biol. Chem. 261: 12665-12674.

7. Hurley, M. M., Abreu, C., Harrison, J. R., Lichtler, A. C., Raisz, L. G. and Kream, B. E. 1993. Basic fibroblast growth factor inhibits type I collagen gene expression in osteoblastic MC3T3-E1 cells. J. Biol. Chem. 268: 5588-5593.

8. Jee, W. S. S., Li, X. J., Inoue, J., Jee, K. W., Haba, T., Ke, H. Z., Setterberg, R. B. and Ma, Y. F. 1997. Histomorphometric assay of the growing bones. pp. 87-112. In: Handbook of Bone Morphometry (Takahashi, H. ed.), Nishimura Co., Ltd., Niigata.

9. Jilka, R. L., Weinstein, R. S., Takahashi, K., Parfitt, A. M. and Manolagas, S. C. 1996. Linkage of decreased bone mass with impaired osteoblastogenesis in a murine model of accelerated senescence. J. Clin. Invest. 97: 1732-1740.

10. Kajkenova, O., Lecka-Czernik, B., Gubrij, I., Hauser, S. P., Takahashi, K., Parfitt, A. M., Jilka, R. L., Manolagas, S. C. and Lipschitz, D. A. 1997. Increased adipogenesis and myelopoiesis in the bone marrow of SAMP6, a murine model of defective osteoblastogenesis and low turnover osteopenia. $J$. Bone Miner. Res. 12: 1772-1779.

11. Linkhart, T. A., Mohan, S. and Baylink, D. J. 1996. Growth factors for bone growth and repair: IGF, TGF $\beta$ and BMP. Bone 19: 1S-12S.

12. Martin, I., Muraglia, A., Campanile, G., Cancedda, R. and Quarto, R. 1997. Fibroblast growth factor-2 supports ex vivo expansion and maintenance of osteogenic precursors from human bone marrow. Endocrinology 138: 4456-4462.

13. Matsushita, M., Tsuboyama, T., Kasai, R., Okumura, H., Yamamuro, T., Higuchi, K., Higuchi, K., Kohno, A., Yonezu,
T., Utani, A., Umezawa, M. and Takeda, T. 1986. Age-related changes in bone mass in the senescence-accelerated mouse (SAM) - SAM-R/3 and SAM-P/6 as new murine models for senile osteoporosis. Am. J. Pathol. 125: 276-283.

14. Mayahara, H., Ito, T., Nagai, H., Miyajima, H., Tsukuda, R., Taketomi, S., Mizuguchi, J. and Kato, K. 1993. In vivo stimulation of endosteal bone formation by basic fibroblast growth factor in rats. Growth Factors 9: 73-80.

15. Mazué, G., Bertolero, F., Garofano, L., Brughera, M. and Carminati, P. 1992. Experience with the preclinical assessment of basic fibroblast growth factor (bFGF). Toxicol. Lett. 64/65: 329-338.

16. Nagai, H., Tsukuda, R. and Mayahara, H. 1995. Effects of basic fibroblast growth factor (bFGF) on bone formation in growing rats. Bone 16: 367-373.

17. Nakamura, T., Hanada, K., Tamura, M., Shibanushi, T., Nigi, H., Tagawa, M., Fukumoto, S. and Matsumoto, T. 1995. Stimulation of endosteal bone formation by systemic injections of recombinant basic fibroblast growth factor in rats. Endocrinology 136: 1276-1284.

18. Noda, M. and Vogel, R. 1989. Fibroblast growth factor enhances type $\beta 1$ transforming growth factor gene expression in osteoblast-like cells. J. Cell Biol. 109: 2529-2535.

19. Parfitt, A. M., Drenzner, M. K., Glureiux, F. H., Kanis, J. A., Malluche, H., Meunier, P. J., Ott, S. M. and Recker, R. P. 1987. Bone histomorphometry: Standardization of nomenclature, symbols, and units-Report of the ASBMR histomorphometry nomenclature committee. J. Bone Miner. Res. 2: 595-610.

20. Rodan, S. B., Wesolowski, G., Yoon, K. and Rodan, G. A. 1989. Opposing effects of fibroblast growth factor and pertussis toxin on alkaline phosphatase, osteopontin, osteocalcin, and type I collagen mRNA levels in ROS $17 / 2.8$ cells. $J$. Biol. Chem. 264: 19934-19941.

21. Rosen, D., Miller, S. C., DeLeon, E., Thompson, A. Y., Bentz, H., Mathews, M. and Adams, S. 1994. Systemic administration of recombinant transforming growth factor beta 2 (rTGF- $\beta 2$ ) stimulates parameters of cancellous bone formation in juvenile and adult rats. Bone 15: 355-359.

22. Seno, M., Sasada, R., Iwane, M., Sudo, K., Kurokawa, T., Ito, K. and Igarashi, K. 1988. Stabilizing basic fibroblast growth factor using protein engineering. Biochem. Biophys. Res. Commun. 151: 701-708.

23. Suda, T., Miyama, K., Uchiyama, Y., Katagiri, T., Yamaguchi, A. and Sato, T. 1994. Osteoporotic bone changes in SAMP6 are due to a decrease in osteoblast progenitor cells. pp. 4752. In: The SAM Model of Senescence (Takeda, T. ed.), Elsevier Science, Tokyo.

24. Takahashi, K., Tsuboyama, T., Matsushita, M., Kasai, R., Okumura, H., Yamamuro, T., Okamoto, Y., Toriyama, K., Kitagawa, K. and Takeda, T. 1994. Modification of strainspecific femoral bone density by bone marrow-derived factors administered neonatally: a study on the spontaneously osteoporotic mouse, SAMP6. Bone Miner. 24: 245-255.

25. Takeda, T., Hosokawa, M. and Higuchi, K. 1997. Senescence-accelerated mouse (SAM): A novel murine model of senescence. Exp. Gerontol. 32: 105-109.

26. Tsuboyama, T., Takahashi, K., Matsushita, M., Okumura, H., Yamamuro, T., Umezawa, M. and Takeda, T. 1989. Decreased endosteal formation during cortical bone modelling in SAMP/6 mice with a low peak bone mass. Bone Miner. 7: 1-12.

27. Tsukuda, R., Shino, A., Tsuda, M. and Matsuo, T. 1986. Bone changes in the senescence-accelerated mouse (SAM) 
reared under specific pathogen-free (SPF) conditions. J. Bone Miner. Metab. 4: 121-127.

28. Triffitt, J. T. 1996. The stem cell of the osteoblast. pp. 39-50 In: Principles of Bone Biology (Bilezikian, J. P., Raiz, L. G. and Rodan, G. A. eds.), Academic Press, San Diego.
29. Wieder, R., Wang, H., Shirke, S., Wang, Q., Menzel, T. Feirt, N., Jakubowski, A. A. and Gabrilove, J. L. 1997. Low level expression of basic FGF upregulates Bcl-2 and delays apoptosis, but high intracellular levels are required to induce transformation in NIH 3T3 cells. Growth Factors 15: 41-60. 